\title{
マニラ首都圈郊外における有機性廃棄物の処理実態と その地域内循環の可能性
}

Organic Waste Management and the Potential of its Local Recycle Use in the Suburbs of Metro Manila 古谷 崇* 原 祐二** 村上 暁信*** Armando Palijon**** 横張 真* Takashi FURUTANI Yuji HARA Akinobu MURAKAMI Makoto YOKOHARI

\begin{abstract}
Using the Solid Waste Management Program of Holy Spirit, a neighborhood of Quezon City and the larger Metro Manila area, as a case study, this research aims to further the development of efficient organic waste recycling systems in developing countries. To accomplish this, two aspects of the present system of Holy Spirit are first evaluated: 1) the reduction of organic waste and recycling of compost and 2) the quantity of organic waste and compost produced. Then, the amount of compost that could potentially be utilized on farmland and vacant land within Holy Spirit was measured to determine the possibility of a local recycling system. Our results indicate that, at present, securing buyers for compost is difficult and, therefore, most compost is distributed to large neighboring farm villages. However, our analysis of potential compost-use within the Holy Spirit area demonstrates that a more local compost recycling system is indeed feasible.
\end{abstract}

Keywords: organic waste, recycling system, compost, vacant land, Barangay, Manila

キーワード: 有機性廃棄物, リサイクルシステム, 堆肥, 空地, バランガイ, マニラ

\section{1. 研究背景と目的}

廃棄物の増加による環境問題が世界的に深刻化している。とり わけ，アジアの開発途上国においては，社会基盤や法制度が未整 備のまま都市圈への人口集中が進んだため, 都市部での廃棄物が 急増し，深刻な都市環境問題が発生している ${ }^{11}$ 。そうした途上国 都市圈における廃棄物は, 成分組成において有機性廃棄物の割合 が高いという特性がある ${ }^{22}$ 。有機性廃棄物は, 高い水分量を保ち, 悪臭を放つなど，都市の生活環境に直接影響を及ぼす。さらには， 過剩な水分を含み嵩が張るため, 埋立処分場寿命の聥減, 焼却場 炉内温度の低下などをもたらし, 全体的な廃棄物処理負荷を増大 させる ${ }^{3)}$ 。廃棄物から有機性廃棄物を選択的に取り除くことがで きれば, 最終処分量の減少だけではなく, 収集・一時貯留や, 再 資源化可能物を分別する上でも大きな便益が得られる ${ }^{4)}$ 。

ところで，アジアの開発途上国においては，有機性廃棄物の増

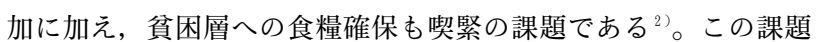
を解決するための一施策として, 都市農業の振興が挙げられる。 都市農地で生産された青果は, 貧困層の栄養状態改善に直接寄与 するとともに, 新たな雇用機会を提供するなど, 種々の副次的効 果む見込まれる ${ }^{5)}$ 。そうした都市農地に近接した住宅地から発生 する有機性廃棄物を堆肥化し, 農地に還元利用することで, 廃棄 物排出量の削減と都市農業の振興を同時達成できる可能性が指摘 されている ${ }^{6)}$ 。しかしながら, 有機性廃棄物の循環利用を目的と した施策の実施現場では, 運用上の課題の一つとして, 生成堆肥 の利用先確保の難しさが指摘されている ${ }^{7)}$ 。その一方で, アジア 都市圈では投機的な空地を包含した形で都市的土地利用が拡大す るとの報告も多く存在する ${ }^{8), 99}$ 。投機的思惑で保有されている空 地は, 農的活動を通じ, 堆肥の潜在的な利用先として期待される ものの, その実現可能性を論じるための実証的な現地研究は不足 している。さらには, そもそもアジア開発途上国の有機性廃棄物 の発生特性, 処分・処理に関する研究蓄積自体十分とはいえない。
その端緒として, 事例研究を通じた有機性廃棄物の利用実態の把 握，および現状問題点の抽出を進める必要がある ${ }^{4)} 。$

以上のような観点から, 本研究では, アジアの開発途上国のひ とつであるフィリピンのマニラ首都圏において, 有機性廃棄物利 用を先進的に行っている事例を対象に，有機性廃棄物の処理実態 を解明することを目的とする。具体的には，1）行政団体，個人 の有機性廃棄物の削減, および農地還元に関する取り組みの現状 把握 2）地域内から発生する生ゴミなど有機性廃棄物の量，およ び堆肥製造供給量の定量的な把握，の以上 2 点を，現地調査によ り行う。さらに，地域内循環システム構築の可能性について検討 するため，3）堆肥受容先としての空地の規模と分布特性を明ら かにし，堆肥受容ポテンシャルの算出を行う。以上の 1)〜3）の 結果より, 研究対象地域における有機性廃棄物の循環利用を目指 す上で必要な現状システムの要改善点を解明する。

\section{2. 研究対象地域}

フィリピン・マニラ首都圈のケソン市に位置するバランガイ・ Holy Spirit（以下，ホーリースピリット）を事例対象地区とす る（図-1)。バランガイは，地方自治法 (Local Government Code）に規定された最末端の地方議会政府であり，その議長と 議員は選挙で選ばれる。活動財源は市または町政府へ収納される 不動産税の $10 \%$ が充てられる。バランガイ議会は，議長と 6 人 の議員, 青年バランガイ, および議長によって任命された書記と 会計係の計 10 名で構成されている。書記と会計係は議決権がな い。バランガイの特徵として, バランガイ・キャプテンの権限が 強いことがあげられる ${ }^{10)}$ 。

ケソン市はマニラ市の北東に隣接する面積 $161.12 \mathrm{~km}^{2}$ ，人口 $2,173,831$ 人 (2000 年ケソン市人口統計より) の市で, 142 のバ ランガイが存在している。ホーリースピリットは，面積 $3.28 \mathrm{~km}^{2} ， 人$ 口 89,456 人（2000 年ケソン市人口統計より）のケソン市最大の

\footnotetext{
"東京大学大学院新領域創成科学研究科 **東京大学サステイナビリティ学連携研究機構 **筑波大学大学院システム情報工学研究科 ***フィリピン大学ロスバニョス校林業・生物資源学科
} 
バランガイである。ホーリースピリット内には, 農地として登記 されている区画はなく ${ }^{11}$, 全域住宅地である。

ケソン市は, フィリピン国内で有機性廃棄物の循環利用に先行 して取り組んでいる自治体である ${ }^{12}$ 。その中でも, ホーリースピ リットは, 有機性廃棄物の循環利用に向け, 具体的な取り組みを 進めている数少ない事例である ${ }^{13}$ 。そのため, 有機性廃棄物処理・ 処分システムの実態解明および要解決課題の抽出という研究目的 を達成するために，特に適した事例地区だと考えられる。

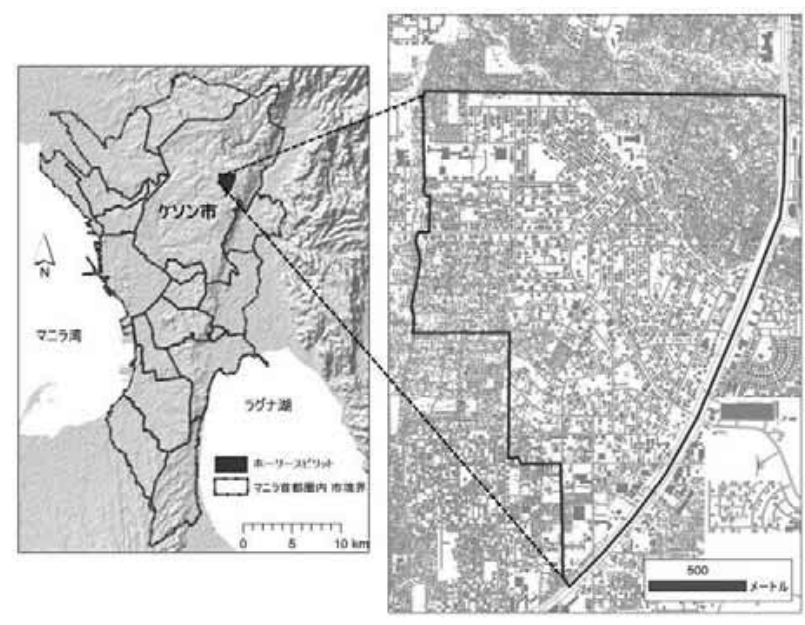

図-1 研究対象地域

3. ケソン市当局およびホーリースピリットにおける廃棄物処理・ 処分に関する取り組みの現状把握

(1) 方法

（i ）ケソン市における取り組み

ケソン市全体としての廃棄物処理・処分に関する取り組みを把 握するため, 2007 年 9 月に, ケソン市役所内の廃棄物管理担当 局である Environmental Protection and Waste Management Department (EPWMD) において, 廃棄物処理に関する各種法 規, 実際の取り組みに関する内部用報告書・統計資料を収集する とともに, 担当官に対し, 施策の具体的な内容, 運用年数, 運用 上の問題点について, 聞き取り調査を行った。

（ii）ホーリースピリットにおける取り組み

ホーリースピリットにおける廃棄物処理・処分に関する取り組 みを把握するため, 2007 年 9 月に, 現地のバランガイ・オフィ スにおいて，バランガイ・キャプテン，廃棄物処理担当者に対し， 有機性廃棄物の回収 - 分別状況, 堆肥製造状況, 堆肥施用状況に ついて聞き取り調査を行った。その後, バランガイ内に立地して いる有機性廃棄物収集に関わるいくつかの施設を訪問し, 運用状 況を調査した。さらに，バランガイ担当職員に協力・同行のもと, 実際に稼働しているゴミ収集車の後を追尾しながら, 収集時の状 況を把握した。

(2) 結果

(i ）ケソン市における Ecological Solid Waste Management Act of 2000 ：RA9003 の運用状況

フィリピンでは, 廃棄物による環境污染が深刻化し, 1999 年 6 月に制定された大気浄化法 The Clean Air Act of 1999 : RA8749により廃棄物の焼却処分が実質的に禁止された。そのた め, 有機性廃棄物を含めて全ての廃棄物が埋立処分されなくては ならなくなった。また， 2001 年 1 月に公布された廃棄物管理に 関わる共和国法 Ecological Solid Waste Management Act of 2000 ：RA9003（以下 RA9003 と記す）により, 最終処分場は閉 鎖するか, あるいは衛生埋立てへ改善することが求められた。こ の 2 つの共和国法により, フィリピンでは, 廃棄物の Reduce,
Reuse, Recycle（3R）が国家レベルの目標とされた。RA9003 では, 市や町などの地方自治体は, リサイクルや有機性廃棄物の 堆肥化の推進により, 最終処分量の $25 \%$ 減量, 衛生埋立て以外 の最終処分場の閉鎖もふまえた廃棄物管理計画 (Solid Waste Management Plan, 以下 SWMP) を策定すること，また，最 小行政単位であるバランガイにおいては，リサイクルや有機性廃 棄物の堆肥化を行う施設 Materials Recovery Facility（以下, $\mathrm{MRF}$ ）を設置し，有価物の分別収集とリサイクル及び堆肥化を 推進することなどが定められている ${ }^{14)}$ 。

マニラ首都圈において最初に SWMP を策定したのがケソン市 であり，その運用当局が EPWMD である。SWMP は 2001 年か ら運用が開始された。ケソン市全体としての廃棄物発生量削減目 標に向け, EPWMD は市内の各バランガイに対し，廃棄物管理 委員会の組織化や MRF の設置指導・運用状況の確認, 廃棄物発 生量削減を進めるための計画支援, インセンティブ付与などを行っ ている。例えば，インセンティブ付与としては，バランガイが独 自にゴミの分別回収を行い, 従来のケソン市が運用するゴミ回収 トラックの派遣回数を半分以下に削減した場合には, 削減によっ て節約できた費用の半分を払い戻し，バランガイが自前の廃棄物 削減・回収システムを達成した場合には，削減費用の全額を払い 戻すなどの施策を実施している。しかし聞き取りによると， SWMP 運用開始から現在まで 6 年が経過しているが, MRF の 設置まで完了しているバランガイはケソン市内全バランガイの $34 \%$ にどまっている ${ }^{15)}$ 。また，バランガイ・キャプテンが廃棄 物管理計画の推進に否定的で計画自体が実行されない事例, バラ ンガイ・キャプテンの交代により既存計画が停止してしまう事例 などがみられ，ケソン市当局のバランガイに対する指導・調整能 力には限界もあることが分かった。

（ii）ホーリースピリットにおける有機性廃棄物削減への具体的 な取り組み内容と有機性廃棄物フローの実態

ホーリースピリットは, その人口・財政規模が比較的大きいこ とや, バランガイ・キャプテンが環境問題に高い関心を持ってい たことから，ケソン市による SWMP 策定（2001 年）以前より， 廃棄物排出量の削減に積極的に取り組んできた。このため, すで にホーリースピリットは, ケソン市派遣のゴミ収集車に頼らない, バランガイ独自の廃棄物収集システムを構築している。ケソン市 による SWMP 策定後は, とりわけ有機性廃棄物の堆肥化事業を, 廃棄物排出量削減の中核と位置づけている。

現地調査により，ホーリースピリットにおける現状の有機性廃 棄物フローは，以下のとおりの実態であることが明らかになった。 (1)バランガイ所有のゴミ収集車（圧縮型ゴミ収集車ではない，普 通荷台のトラック） 6 台が，週 2 回，バランガイ内で 3 つに分 けられた地区毎に収集を行っている。

(2)バランガイ・オフィスで聞き取った公式見解では, 世帯からゴ ミが排出される時点で, 有価物, 堆肥化可能な有機性廃棄物, その他の 3 種に分別されるとのことだった。しかし, 実際の世 帯からの排出およびゴミ収集車による回収の現場を視察したと ころ，世帯段階では有機性廃棄物は分別されておらず，収集後， 数名の収集員により, ゴミ収集トラック荷台上にて 3 種に分別 されていた。

(3)ゴミ回収後, トラックは MRF に集結し，まずは有価物の換金 のため, 分別した有価物と, 有機性廃棄物の重量測定を行う。 その後有価物は廃品業者に売却され，その換金分はゴミ収集員 の収入となる。また，分別しきれなかった有機性廃棄物は，他 の非再生ゴミと混合したまま最終処分場へ運ばれている。

(4)分別の上, MRF に集められた有機性廃棄物は, MRF 敷地内 にて稼働している 6 台のコンポストドラムを用いて堆肥化される。 (5)生成された堆肥は, MRF に近接するバランガイ運営農地 
(Eco Center) に投入, 利用されている。しかし，それだけで は供給過多となるため, バランガイ外の農家への販売も行って いる。

(6)分別収集された有機性廃棄物の全量が堆肥化されているわけで はなく, 余剩分はケソン市外の養豚業者に販売している。

図一 2 は，以上把握されたホーリースピリットにおける現状の 有機性廃棄物フローを，モデルとして表現したものである。

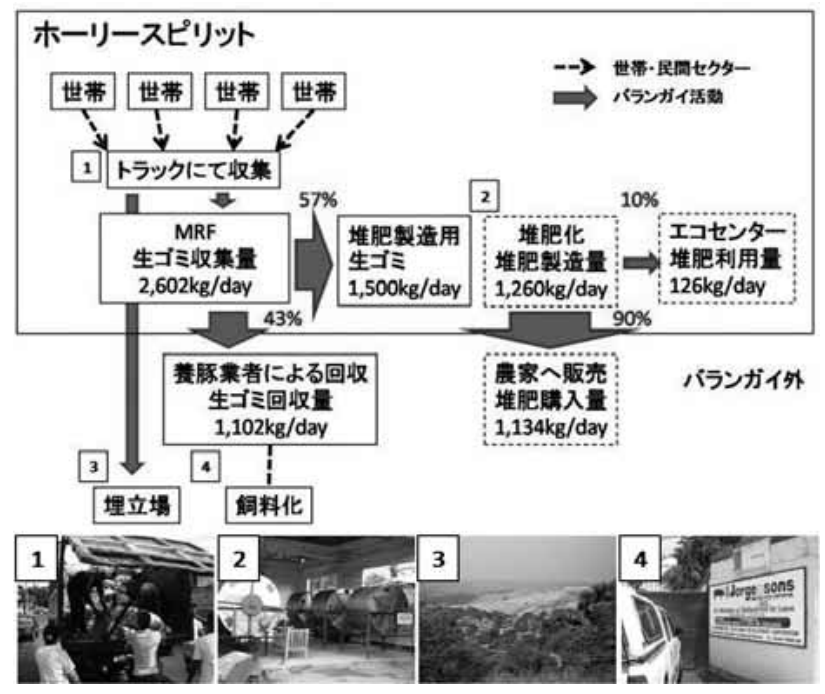

図ー2 ホーリースピリットにおける有機性廃棄物フローモデル

\section{4. ホーリースピリットにおける有機性廃棄物フローの定量化}

(1) 方法

有機性廃棄物フローをより定量的に把握するため, 2008 年 3 月にホーリースピリットの MRF にある管理事務室を訪問し, バ ランガイ公式統計として記録・保管されていた有機性廃棄物収集 量のデー夕（2007 年 11 月〜2008 年 1 月のもの）を入手した。こ のデータは MRF における毎日の重量測定後に, 測定結果を収集 員が記録したものである。また, MRF 担当者への聞き取りを通 じ, コンポストドラムへの有機性廃棄物投入量, 堆肥製造量, 外 部への堆肥販売量及び堆肥製造量に対する割合, 地域内における 堆肥施用割合, 養豚業者による買い取り量を把握した。エコセン ターにおける堆肥施用量は, エコセンター担当者への聞き取りに より得た。また, 住民によるバランガイ製堆肥の利用状況を把握 するため, ホーリースピリット内全域から空間的に均等分布する 様に抽出した 25 世帯を訪問し, 堆肥施用の有無とその理由に関 して聞き取り調査を行った。

\section{(2) 結果}

ホーリースピリット全域における分別された有機性廃棄物の平 均収集量は, $2,602 \mathrm{~kg} /$ day であった。そのうち, 堆肥製造に利 用される有機性廃棄物量は $1,500 \mathrm{~kg} /$ day である。すなわち, 6 台あるコンポストドラムのうちの 1 台に, 毎日有機性廃棄物の新

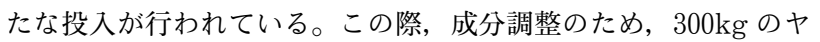
シ粉末も同時に加えられている。一回の堆肥製造のため, コンポ ストドラムは一週間稼働する必要がある。したがって, 6 台のコ ンポストドラムをフル稼働すれば, 切れ目なく毎日新たな有機性 廃棄物を, 空のコンポストドラムに投入することができる。こう して製造される堆肥量は, 水分含有量が低下するため, $1,260 \mathrm{~kg} /$ day である。一方, 収集・分別された有機性廃棄物の うち, 堆肥化されない分は, ケソン市外から来る養豚業者によっ て回収されているという回答を得た。その量は, 有機性廃棄物収 集量からコンポストドラムへの日投入量を差し引いた $1,102 \mathrm{~kg} /$ day と推算される (図一 2 )。
生成された堆肥のうち, 地域内での施用量はエコセンターのみ であり, 日単位基準に平均すると, 製造量全体の $10 \%$ 程度, つ まり $126 \mathrm{~kg} / \mathrm{day}$ 程度であるという。担当者によれば, 残りの 90 \%は農家, とりわけホーリースピリット外, さらにはケソン市外 から買い付けに来る農家への販売に充てられているとのことだっ た。一方，バランガイ住民への聞き取りでは，聞き取り対象とし た全世帯が堆肥を利用していないと回答している。その理由とし て, 84\%の世帯が, 堆肥を利用する場所がないことを挙げた。こ の結果からも, 堆肥の販売先として, ホーリースピリット外の農 家が重要な位置を占めているといえる（図－2）。担当者の証言 通り, ケソン市外から多くの農家が堆肥の買い付けに来ていると すれば，堆肥の多くはバランガイ外の遠方地域に運送されている ことになる。

\section{5. 有機性廃棄物のバランガイ内循環の可能性}

\section{(1) 方法}

以上把握された有機性廃棄物を地域内で循環させるシステムを 構築する可能性について検討すべく, 堆肥受容先として空地を想 定し, それらの堆肥受容ポテンシャルの算出を行った。そのため にまず，ホーリースピリット内の空地の空間分布を把握した。

\section{(i) 空地分布図の作成}

2003 年撮影の 5000 分の 1 オルソグレースケール空中写真と, 2003 年に JICA 支援により Metro Manila Development Authority が作製した 5000 分の 1 都市計画基本図を重ね合わせ, 対象地区に扔ける空地をポリゴンデータとして作成・抽出した。 なおここでは, 空地とは, 建物, 道路, 水域（河川, 湖沼)を除 いた，樹林もしくは草本に覆われた空間および，裸地とした。

作業には GIS ソフトウェア ArcGIS9.2（ESRI 社）を用いた。 建物, 道路, 壁, 水域の判読は都市計画基本図上で行い, 空地の 抽出は航空写真の目視判読により行った。判読不明な箇所は, 2008 年 3 月 28 日〜30 日にかけて実施した現地踏查により判断し た。最終的には, 空地の総面積, 平均規模, 空地率 (対象地の総 面積に占める空地の割合) を求めた。

（ii）バランガイ内空地の堆肥受容ポテンシャルの算出

（i）により作成された空地分布図と，エコセンターによる堆肥 施用量を参考に, バランガイ内空地の堆肥受容ポテンシャル量を 推定し, 現状の堆肥製造量と比較検証する。堆肥施用量として, バランガイで製造した堆肥を実際に利用しているエコセンターに おける聞き取り調查から明らかになった值を用いた。エコセンター 運営管理者は, ケソン市主催の営農講習会などにも積極的に参加 し, 堆肥の成分基準に基づいた成分調整の重要性に対する認識も 持っていた。その影響もあり, エコセンターでは, MRF で製造 され持ち込まれた堆肥に, 䳕粪, 籾殼, 土をそれぞれ $25 \%$ 土゙つ 配合し, 肥料を生成, 畑に実際に投下していた。結局, エコセン 夕ー内の 0.6ha の農地に対し, 年間 20t の堆肥を施用するという 值を得, 計算に用いた。

(2) 結果

(i ) 堆肥受容見込み先としての空地の規模, 分布特性

2003 年の空中写真基準で, ホーリースピリット内に, 1344 ヶ 所の空地が確認された（図－3）。空地率は $17.4 \%$ あった。空

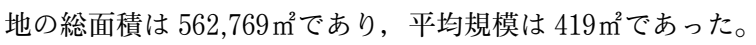

現地踏査によれば, 図一 3 中北東部はスクォッ夕ー占有地区で あり, 低所得者が密集して生活していた。そのため, 空地の割合 が少ないと考えられた。一方, 図一 3 中南西部には, 社会基盤が 整備された住宅地が分布していた。同地区においては, 投機的目 的から土地のみが購入され, 建物の建設がなされないまま空地之 なっている場合が比較的多かった。 


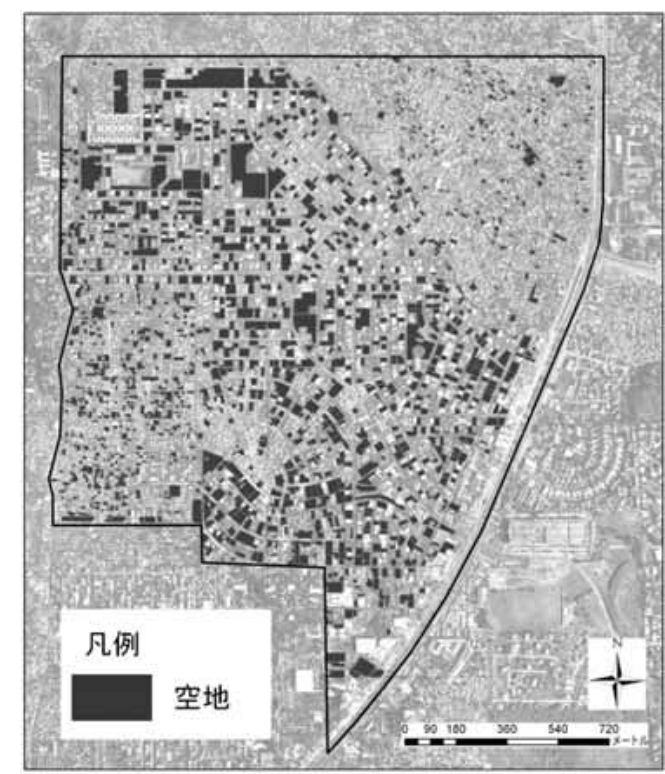

図ー3ホーリースピリット内の空地分布図 （空中写真画像に重ねて表示）

（ii）現状空地の堆肥受容ポテンシャル, 有機性廃棄物の地域内 循環構築可能性の検討

算出されたホーリースピリット内空地の堆肥受容ポテンシャル を, 現状の堆肥製造量と併せて検討を行った。空地を堆肥受容先 として, エコセンターと同様な形態で利用することが可能である という前提の下では, 現在の堆肥製造量の約 4 倍の堆肥受容ポテ ンシャルがあると推算された。すなわち, 現存している空地の約 $25 \%$, 堆肥受容地としてエコセンターと同様な形態で利用する ことがもし可能であれば，バランガイ内で製造された堆肥をバラ ンガイ内で消費し得ることが示唆された。

\section{6 . 総合考察・ 今後の課題}

ケソン市全体の廃棄物排出量を抑制するため, ケソン市当局 EPWMD は, 実際の現場における廃棄物管理の主体であるバラ ンガイに対し, 各種インセンティブの付与などを通じて廃棄物の 排出量の削減を促していた。その中で，ホーリースピリットは， 有機性廃棄物の堆肥化を廃棄物排出量削減の中核として位置付け, 生成堆肥の利用先であるエコセンターの運営までも含め事業を推 進していた。現地調査により明らかとなった, 実際の有機性廃棄 物フロー（図一 2) によれば, エコセンターを除くと, バランガ イ内での堆肥の受容先が確保されず, 製造された堆肥はバランガ イ外, とりわけケソン市外へと販売されていた。また, MRFに 投入する有機性廃棄物量を調整し, 残部はケソン市外の養豚業者 により飼料化が行われている実態が把握された。これは生成堆肥 の供給過多を防ぐ目的もあると推測される。

現状では, 有機性廃棄物の物質フローは, バランガイ外, とり わけケソン市外に隣接する農村部までをも含めた広域空間で成立 している。一方で, バランガイ内の空地 (図-3) を, 堆肥の受 容見込先として位置付けた場合, 現状の堆肥製造量をバランガイ 内で消費可能であることがわかった。近年, 石油などの資源価格 が高騰し, 輸送費の上昇が推定されるため, できる限り小規模な 地域内での循環系構築の重要性が高まると考えられる。そのため の一施策として, 地域内における空地を有効活用し, 農的活動の 強化を通じた生成堆肥の投入先として, バランガイ内の空地を計 画的に位置付けることが考えられる。実際に, 現地踏査により投 機的な空地を近隣住民が農的に利用している事例を, 隣接地域に おいて確認した。そこでは, 空地の管理という名目で, 土地所有
者が近隣住民に空地を農的に利用することに対し許可を与えてい た（図ー4）。このような事例を，ホーリースピリットにおいて 屯実現するためには，バランガイが耕作者と空地所有者との仲介 を行うといった具体策が想定される7゙。
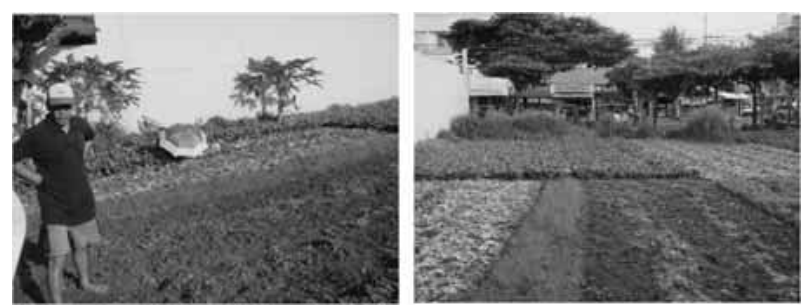

図ー4＼cjkstart近隣住民による空地の農的利用の例

今後, 地域内における有機性廃棄物循環に資する施策・シナリ 才を提示していくためには，有機性廃棄物フローのさらなる実態 把握・定量化が必要である。同時に，バランガイの持つ政策実行 力の解明, 住民・土地所有者の有機性廃棄物削減に対する詳細な 意識調査，ケソン市ーバランガイー住民といった各主体間の関係 解明など，さらなる社会調査も必要である。

\section{謝辞}

本研究を進めるにあたり, EPWMD 廃棄物担当官, バランガ イ長・職員の方々には有益な情報をご提供頂いた。また, 調査地 近隣の住民の方々にご協力頂いた。深く感謝申し上げる。なお， 本研究は, 平成 19 年度旭硝子財団研究助成により行われた。

\section{引用文献}

1 ) 高橋裕 ・加藤三郎・武内和彦・安城哲三 ・和田英太郎 (1998)：「岩 波講座地球環境学 8 地球環境亡巨大都市」: 岩波書店, $290 \mathrm{pp}$

2 ）社団法人海外環境協力センター (2004) : 廃棄物分野における国際協 力のあり方 配慮すべき基本的事項について: 廃棄物分野国際協力研 究会, $58 \mathrm{pp}$

3 ）滝沢塁・村上公哉（2001）：生ゴミの堆肥化処理と焼却処理のエネル ギー消費量の比較調查：日本建築学会大会学術講演梗概集 Vol.2001, $1037-1038$

4 ）小島道一（2008）：アジアにおけるリサイクル：アジア経済研究所,

5) Midmore, D.J. and Jansen, H.G.P. (2003) : Supplying vegetables to Asian cities: is there a case for peri-urban production? Food Policy 28, 13-27

6 ）武内和彦・原祐二（2006）：アジア巨大都市における都市農村循環社 会の構築：農村計画学会誌 Vol.25 No3, 201-205

7 ） 小林一幸・横張真・村上暁信・渡辺貴史（2005）：マニラ首都圈の都 市農業振興事業における地域自治組織の役割：農村計画論文集 No.7, $229-234$

8 ) Murakami, A., Zain, A.M., Takeuchi, K., Tsunekawa, A. \& Yokota, S. (2005): Trends in urbanization and patterns of land use in the Asian mega-cities Jakarta, Bangkok, and Metro Manila. Landscape and Urban Planning 70, 251-259

9 ) Hara, Y., Ogasawara, T., Palijon, A.M. and Takeuchi, K. (2007): Quantitative and qualitative characteristics of greenery in suburban residential districts of Metro Manila. Proceedings of International Symposium on City Planning, 418-427

10）大坪省三（2001）：都市中間層のコミュニティと地方自治，中西徹・ 小玉徹・新津晃一編,「アジアの大都市 4 マニラ」: 日本評論社, 219-244

11) Quezon City (2000) : Comprehensive Land Use Plan, 57.

12) Environmental Protection and Waste Management Department (2005) : The Great Quezon City Clean-up Solid Waste Management of Quezon City, 92pp

13) Constancio, C, De, Gunzman, Virgina, C, Cuevas, Zenaida, M, Sumalde, Blanda, R, Sumayao, Sixto, A, Valencia. Wilfredo, C, Cosico, (2006): Final Report Biowaste Reuse in Southeast Asian Cities Metro Manila Component, 207pp

14) Department of Environment and Natural Resources Environmental Management Bureau (2000) : Republic Act 9003 and its Implementing Rules and Regulations (IRR), pp69

15) Environmental Protection and Waste Management Department (2007) : Program Evaluation Sinop Basura Sa Barangay A Community-Based Solid Waste Management Program for Quezon City, 8pp 